\begin{tabular}{cc|c}
\hline Tar. Bil. Der. & Tarm Bilimleri Dergisi & Journal of Agricultural Sciences \\
& $\begin{array}{c}\text { Dergi web sayfası: } \\
\text { www.agri.ankara.edu.tr/dergi }\end{array}$ & Journal homepage: \\
& www.agri.ankara.edu.tr/journal
\end{tabular}

\title{
Effects of Clinoptilolite on the Digestibility of Nutrients and Relative Organ Weights in Rat Diets
}

\author{
Ramazan DEMIREL ${ }^{\mathrm{a}}$, Murat Sedat BARAN ${ }^{\mathrm{b}}$, Dilek Şentürk DEMIREL ${ }^{\mathrm{a}}$, Aydın KETANíc, Beran YOKUŞ ${ }^{\mathrm{d}}$ \\ ${ }^{a}$ Dicle University, Faculty of Agriculture, Department of Animal Science, Feeds and Animal Nutrition, Diyarbakur, TURKEY

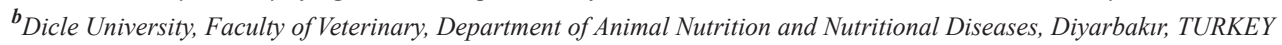 \\ ${ }^{c}$ Dicle University, Faculty of Veterinary, Department of Histology and Embryology, Diyarbaku, TURKEY \\ ${ }^{d}$ Dicle University, Faculty of Veterinary, Department of Biochemistry, Diyarbakır, TURKEY
}

\section{ARTICLE INFO}

Research Article DOI: 10.15832/ankutbd.451270

Corresponding Author: Murat Sedat BARAN, E-mail: msedatbaran@dicle.edu.tr, Tel: +90 (542) 7898401

Received: 24 July 2017, Received in Revised Form: 01 August 2017, Accepted: 17 September 2017

\begin{abstract}
This study was conducted to compare the effects of dietary clinoptilolite on nutrient digestibility and relative organ weights in rats. In this study, 24 adult male Sprague-Dawley rats were divided into 4 groups with 3 replicates, according to a randomized split plots design. In addition to a control group ( $0 \%$ clinoptilolit), 3 levels of clinoptilolite ( $2 \%, 4 \%$, and $6 \%$ ) were used in the diets, and the rats were fed (individually in cages) these diets for 56 days. Statistically significant differences were found among the groups for the digestibility rates of nutrients $(\mathrm{P}<0.05)$, except for crude fibre $(\mathrm{CF})$ and acid detergent fibre (ADF). The addition of clinoptilolite in rats' feeds reduced the digestibility of crude fibre, crude ash (CA), neutral detergent fibre (NDF) and acid detergent fibre (ADF), but increased the digestibility of other nutrients. Slaughter live, organs (liver, kidney, heart, and stomach) and relative organ weights were not affected significantly by the clinoptilolite contents $(\mathrm{P}>0.05)$. In conclusion, clinoptilolites can be used in animal feed as natural toxin binders when stored under suitable conditions.
\end{abstract}

Keywords: Clinoptilolite; Feed; Nutrient digestibitiy; Relative organ weight; Rat

(C) Ankara Üniversitesi Ziraat Fakültesi

\section{Introduction}

Zeolites are used for various applications, for example; as natural toxin binders in industry, agriculture, veterinary medicine and environmental protection. Clinoptilolite is usually one of the alumino silicate minerals on the volcanic rocks (Baran \& Kutay 1999; Martin-Kleiner et al 2001). Natural zeolite, especially clinoptilolite and analysim, are the most rich types in some regions of Turkey (Baran \& Kutay 1999).
Different types and doses of zeolites have been studied previously in different animal diets, such as in broiler diets, with sodium bentonite (Eraslan et al 2005); in quail diets with HSCAS (Şehu et al 2005); in dairy cows adding zeolite (Dschaak et al 2010) in broiler and piglet diets adding clinoptilolite (Tang et al 2015) in rat diets adding HSCAS (Afriyie-Gyawu et al 2005), clinoptilolite (Martin-Kleiner et al 2001; Demirel et al 2011) and Tunus montmorillonit clay (TMC) (Abbès et al 2007). The clinoptilolite 
protected the animals from the toxic effects of the mycotoxins (Abdel-Wahhab et al 1999).

The digestibility rates of nutrients have been studied by different researchers in various animal species, such as in a project that investigated the digestibility rates of sorghum grains in broiler diets when they were exchanged for dry matter (DM), CA, crude protein $(\mathrm{CP})$ and nitrogen-free extract matter (NFE) (Adama et al 2007). The digestibility rates of wheat and sorghum grains in beef cattle diets were determined for DM, organic matter (OM), CP, EE, CF, NFE, ADF, NDF and CA (Baran et al 2008). In another study, DM and OM digestibility were similar (Baran et al 2017).

In rat diets, the digestibility rates of $\mathrm{DM}, \mathrm{CP}, \mathrm{EE}$, and CA values were found to be 86.20, 81.66, 94.95, and $56.89 \%$, respectively (Ahlstrom \& Skrede 1998). In comparing rat diets based on rapeseed+barley and wheat bran+oats with respect to the apparent digestibility of DM and CF and the true digestibility of $\mathrm{CP}$, feed intake did not affect the digestibility of the major feed components (Larsen et al 1991). However, there is limited literature related to the effects of clinoptilolite on the digestibility rates of nutrients. It has been demonstrated that improved nitrogen, $\mathrm{OM}$ and ADF digestibility was achieved when $5 \%$ levels of clinoptilolite were given to a high-solubility protein diet (Sweeney et al 1980). It has been stated that the apparent digestibility rates of clinoptilolite in growing piglet diets for DM,
$\mathrm{OM}, \mathrm{CP}, \mathrm{CF}, \mathrm{EE}, \mathrm{NDF}$ and $\mathrm{ADF}$ ranged from 83.5$87.0 \%, 88.1-89.2 \%, 88.1-88.2 \%, 58.6-65.9 \%, 83.8-$ $85.6 \%, 67.8-70.9 \%$ and $59.0-59.8 \%$, respectively (Fokas et al 2004). Dietary clinoptilolite did not significantly affect the investigated parameters, except for an increase in EE.

This research was performed to define the effects of various contents of dietary clinoptilolite on the digestibility rates of some nutrients (DM, CP, EE, $\mathrm{CA}, \mathrm{CF}, \mathrm{OM}, \mathrm{NFE}, \mathrm{ADF}$ and NDF) and relative organ weights in rats.

\section{Material and Methods}

\subsection{Zeolitic material}

Zeolite purchased from Manisa, Turkey. The chemical content of clinoptilolite was as follows: $\mathrm{SiO}_{2}, \mathrm{CaO}, \mathrm{Fe}_{2} \mathrm{O}_{3}, \mathrm{Al}_{2} \mathrm{O}_{3}, \mathrm{~K}_{2} \mathrm{O}, \mathrm{MgO}, \mathrm{Na}_{2} \mathrm{O}, \mathrm{TiO}_{2}$, $\mathrm{MnO}$, LOI (loss on ignition at $1000{ }^{\circ} \mathrm{C}$ ), $\mathrm{SiO}_{2} /$ $\mathrm{Al}_{3} \mathrm{O}_{2}$ as 65-72, 2.5-3.7, 0.8-1.9, 10-12, 2.3-3.5, $0.9-1.2,0.3-0.65,0-0.1,0-0.08,9-12$, and 5.4-6.0\%, respectively (Anonymous 2012).

\subsection{Feed and feeding}

Experimental diets were prepared at the Veterinary Faculty. Pelleted feed was produced for rats. All of the diets were arranged to be iso-caloric and iso-nitrogenic (National Research Council 1995). The chemical compositions of the diets are given in Table 1 .

Table 1- Chemical compositions of diets used in trial

\begin{tabular}{lcccc}
\hline \multirow{2}{*}{ Crude nutrients } & \multicolumn{4}{c}{ Chemical composition, \% } \\
\cline { 2 - 5 } & $I($ control $)$ & $I I(2 \%$ zeolite $)$ & III (4\% zeolite) & $I V(6 \%$ zeolite $)$ \\
\hline Dry matter & 93.55 & 94.15 & 94.40 & 95.10 \\
Crude protein & 22.41 & 22.58 & 22.65 & 22.45 \\
Ether extact & 13.36 & 13.76 & 14.49 & 15.54 \\
Crude ash & 8.05 & 9.10 & 10.02 & 10.40 \\
Organic matter & 85.50 & 85.05 & 84.38 & 84.70 \\
Nit. free extract & 40.23 & 38.56 & 36.04 & 34.66 \\
Crude fiber & 9.50 & 10.15 & 11.20 & 12.05 \\
Acid detergent fiber & 16.67 & 19.32 & 20.25 & 18.85 \\
Neutral detergent fiber & 38.08 & 38.76 & 36.65 & 32.71 \\
Energy, Kcal ME kg- ${ }^{-1}$ & 3203 & 3229 & 3211 & 3225 \\
\hline
\end{tabular}

*, calculated 


\subsection{Animals and treatments}

24 male Sprague-Dawley rats (8 weeks old and mean initial weight of $307 \pm 19 \mathrm{~g}$ ) were used in the trial. Feed and water ad libitum were given. The rats were divided into 4 equal groups according to clinoptilolite rates of the diets.

\subsection{Determination of crude nutrients}

$\mathrm{DM}, \mathrm{CP}, \mathrm{CA}$ and $\mathrm{EE}$ analyses of the diets and faeces samples were conducted according to the AOAC (2000) and the crude fibre content was measured according to Crampton \& Maynard (1938). ADF and NDF analyses were performed according to Van Soest (1987). The ME values of the diets were calculated by using the energy content of the feedstuff.

\subsection{Digestibility analysis}

Faeces samples were collected cleanly and dried daily to determine the in vivo digestibility rates of nutrients. Until sufficient amounts of faeces samples were obtained for analysis, during a 28 day sample collection period, this process was repeated. After that, all of the collected materials were ground and prepared for chemical analyses. In this trial, an indicator method was used to determine the digestibility rates of nutrients because of the difficulty of collecting all the rat faeces. The insoluble ash content in $\mathrm{HCl}$ was used as the indicator. The digestibility rates of the nutrients were calculated by the following equation stated by Sarı \& Çerçi (1993).
$D R \%=100-[(I L I F \% / I L I M \%) \times(N I M \% / N I F \%)] \times 100$

Where; $D R$, digestibility rate; ILIF, indicator level in feed; ILIM, indicator level in manure; NIM, nutrients in manure; NIF, nutrients in feed.

\subsection{Relative organ weights}

Determined by using slaughter and organ weights (g $100 \mathrm{~g}^{-1} \mathrm{BW}$ ).

\subsection{Statistical analyses}

The researh was arranged according to a randomized plot design with 4 groups and 3 replicates. Variance Analysis Method was used for statistical analysis of data. Duncan's Test (Duncan 1995) was used to determine differences amongst groups. For statistical calculations, SPSS 10.0 software was used (SPSS 1999).

\section{Results and Discussion}

The average digestibility rates of nutrients (DM, CP, EE, CA, CF, OM, NFE, ADF and NDF) are presented in Table 2. Statistically significant differences were found among the investigated groups for the digestibility rates of nutrients $(\mathrm{P}<0.05)$, except for the DM, CF and ADF levels $(\mathrm{P}>0.05)$. The adding of dietary clinoptilolite significantly increased the digestibility rates of $\mathrm{CP}, \mathrm{EE}, \mathrm{OM}$ and NFE but decreased those of CA and NDF. The highest average digestibility values of nutrients were

Table 2- Average digestibility rates of nutrients, $\%$

\begin{tabular}{|c|c|c|c|c|c|}
\hline \multirow{2}{*}{ Nutrients } & \multicolumn{4}{|c|}{ Groups } & \multirow{2}{*}{ Significance } \\
\hline & I (control) & II (2\% zeolite) & III (4\% zeolite) & $I V(6 \%$ zeolite $)$ & \\
\hline Dry matter & $62.29 \pm 1.13$ & $63.17 \pm 1.14$ & $65.68 \pm 0.66$ & $65.56 \pm 2.38$ & 0.058 \\
\hline Crude protein & $62.66 \pm 1.20 \mathrm{~b}$ & $63.61 \pm 1.11 \mathrm{~b}$ & $67.00 \pm 0.92 \mathrm{a}$ & $67.30 \pm 1.16 \mathrm{a}$ & 0.013 \\
\hline Ether extact & $92.51 \pm 0.64 \mathrm{c}$ & $92.83 \pm 0.38 \mathrm{bc}$ & $93.92 \pm 0.28 \mathrm{ab}$ & $94.24 \pm 0.43 \mathrm{a}$ & 0.037 \\
\hline Crude ash & $47.54 \pm 1.33 \mathrm{a}$ & $37.81 \pm 1.37 \mathrm{~b}$ & $33.33 \pm 0.71 \mathrm{c}$ & $26.96 \pm 0.69 \mathrm{~d}$ & 0.000 \\
\hline Organic matter & $67.96 \pm 1.09 \mathrm{~b}$ & $70.10 \pm 1.05 \mathrm{~b}$ & $73.84 \pm 0.62 \mathrm{a}$ & $74.31 \pm 1.06 \mathrm{a}$ & 0.000 \\
\hline Crude fiber & $16.76 \pm 1.55$ & $14.57 \pm 1.64$ & $12.73 \pm 0.93$ & $14.06 \pm 1.18$ & 0.239 \\
\hline $\mathrm{ADF}$ & $59.84 \pm 1.96$ & $58.57 \pm 1.10$ & $58.75 \pm 1.47$ & $55.32 \pm 1.23$ & 0.191 \\
\hline NDF & $59.94 \pm 1.59 \mathrm{a}$ & $57.12 \pm 1.12 \mathrm{ab}$ & $55.54 \pm 1.00 \mathrm{~b}$ & $49.50 \pm 1.32 \mathrm{c}$ & 0.000 \\
\hline NFE & $74.05 \pm 1.23 \mathrm{c}$ & $82.61 \pm 1.06 \mathrm{~b}$ & $88.68 \pm 0.81 \mathrm{a}$ & $91.08 \pm 1.18 \mathrm{a}$ & 0.000 \\
\hline
\end{tabular}

Tarım Bilimleri Dergisi - Journal of Agricultural Sciences $\quad 24$ (2018) 297-302 
obtained for $\mathrm{CA}, \mathrm{CF}, \mathrm{ADF}$ and $\mathrm{NDF}$ in the control group, for DM in group III, and for CP, EE, OM and NFE in group IV. However, the lowest values were obtained for DM, CP, EE, OM, NFE in the control group, for $\mathrm{CF}$ in group III, and for $\mathrm{CA}, \mathrm{ADF}$ and NDF in group IV.

The average slaughter live, relative organ (liver, kidney, heart and stomach) weights and their analysis of variance results are given in Table 3. Differences among the groups were not found significant for the slaughter live and relative organ weights $(\mathrm{P}>0.05)$.
The highest values were obtained for the slaughter live, liver, kidney and heart weights and their relative weights in the control group and for the stomach and its relative weight in group II. However, the lowest values were obtained for the slaughter, liver, kidney and stomach weights and their relative weights in group III and for the heart and its relative weight in group IV.

Our results for the nutrient digestibility rates in rat diets for DM, CP and CA values were found to be lower than the results of Ahlstrom \& Skrede (1998).

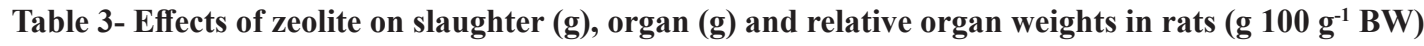

\begin{tabular}{|c|c|c|c|c|c|}
\hline \multirow{2}{*}{ Parameters } & \multicolumn{4}{|c|}{ Groups } & \multirow{2}{*}{ Significance } \\
\hline & $I$ (control) & II (2\% zeolite) & III (4\% zeolite) & IV (6\% zeolite) & \\
\hline Slaughter weight & $358.24 \pm 41.65$ & $352.35 \pm 26.75$ & $345.67 \pm 6.03$ & $353.15 \pm 30.52$ & 0.891 \\
\hline Liver weight & $11.95 \pm 2.56$ & $11.60 \pm 1.35$ & $10.89 \pm 1.07$ & $11.29 \pm 1.25$ & 0.691 \\
\hline Liver rate & $3.31 \pm 0.37$ & $3.29 \pm 0.21$ & $3.15 \pm 0.23$ & $3.20 \pm 0.18$ & 0.704 \\
\hline Kidney weight & $2.95 \pm 0.37$ & $2.88 \pm 0.28$ & $2.73 \pm 0.29$ & $2.84 \pm 0.37$ & 0.654 \\
\hline Kidney rate & $0.82 \pm 0.05$ & $0.82 \pm 0.07$ & $0.79 \pm 0.07$ & $0.80 \pm 0.06$ & 0.762 \\
\hline Hearth weight & $1.31 \pm 0.18$ & $1.23 \pm 0.20$ & $1.25 \pm 0.14$ & $1.18 \pm 0.26$ & 0.670 \\
\hline Hearth rate & $0.37 \pm 0.05$ & $0.35 \pm 0.04$ & $0.36 \pm 0.04$ & $0.33 \pm 0.06$ & 0.573 \\
\hline Stomach weight & $3.92 \pm 0.94$ & $4.63 \pm 0.69$ & $3.66 \pm 1.25$ & $3.75 \pm 0.58$ & 0.276 \\
\hline Stomach rate & $1.08 \pm 0.14$ & $1.31 \pm 0.13$ & $1.05 \pm 0.33$ & $1.08 \pm 0.26$ & 0.237 \\
\hline
\end{tabular}

Fokas et al (2004), found higher digestibility rates with the addition of clinoptilolite in growing piglet diets than those of ours for DM, OM, CP and NDF at $83.5-87.0 \%, 88.1-89.2 \%, 88.1-88.2 \%$ and 67.8 $70.9 \%$ respectively. However, the EE values (83.8$85.6 \%$ ) were lower, while those for ADF were similar to our results.

In addition, Baran et al (2008), found higher digestibility rate ranges for wheat and sorghum grain-based beef cattle diets than those of ours for DM, CF and CA at $69.48-70.50 \%, 59.70-60.30 \%$ and $59.70-60.10 \%$; however, they found lower values for OM, CP, EE, NFE, ADF, and NDF at $68.90-69.30 \%, \quad 69.80-70.20 \%, \quad 70.90-71.40 \%$, $73.90-74.40 \%, 43.20-43.70 \%$ and $46.00-46.40 \%$, respectively.

The total DM digestibility values in this study similar level were observed by Husted et al (1968).
Our digestibility rates for DM were greater than those reported by Sweeney et al (1980) and Johnson et al (1988). The higher DM digestibility values for diets containing zeolite might be due to the higher digestibility of other nutrients such as $\mathrm{CP}$ and a lower rate of passage. In the present work, the CP digestibility values are greater for the zeolite diets (Sweeney et al 1980). Our ADF digestibility results are similar with the findings of Johnson et al (1988). In general, the digestibility rates in this study are found lower than those of related literature findings. The reasons for these differences are due to the use of different animal species and zeolite types and doses.

Our relative organ weight results are similar to the findings of some studies that investigated the use of clinoptilolite in rat diets (Eleroğlu \& Yalçın 2012; Eser et al 2012; Tang et al 2015). 
The dietary clinoptilolite up to $6 \%$ did not have any adverse effects on the clinical health status of rats. Increasing the level of zeolite in animal feed increased the nutrient digestibility in diets such as DM, OM, CP, EE and NFE, except for those of CA and NDF, which decreased. However, the digestibility of $\mathrm{CF}$ and $\mathrm{ADF}$, and the relative organ weights were not affected by clinoptilolite levels. Additionally, increasing levels of nutrient digestibility, lead to economical animal production.

\section{Conclusions}

Clinoptilolites can be used at the level of $2-6 \%$ in animal feed as cheap toxin binders when stored under suitable conditions, especially in poor countries. Clinoptilolite can be preferred to protect farm animals and their products from carcinogenic side effects. Various levels of clinoptilolite may be used for different animal kind to determine the safety margins and therapeutic effects, in further experiments.

\section{References}

Abbès S, Salah-Abbès J B, Nahdi K, Younes R B, Hetta M M, El-Kady A A, Abdel-Wahhab M A \& Queslati R (2007). Inactivation of cadmium induced immunotoxicological alterations in rats by Tunisian montmorillonite clay. International Immunopharmacology 7: 750-760

Abdel-Wahhab M A, Nada S A \& Amra H A (1999). Effect of aluminosilicates and bentonite on aflatoxininduced developmental toxicity in rat. Journal of Applied Toxicology 19: 199-204

Adama T Z, Ogunbajo S A \& Mambo M (2007). Feed intake, growth performance and nutrient digestibility of broiler chicks fed diets containing varying levels of sorghum dried brewers' grains. International Journal of Poultry Science 6: 592-598

Afriyie-Gyawu E, Mackie J, Bhagirathi D, Wiles M, Taylor J, Huebner H, Tang L, Guan H, Wang J S \& Phillips T (2005). Chronic toxicological evaluation of dietary Novasil clay in Sprague-Dawley rats. Food Additives and Contamination 22: 259-269

Ahlstrom O \& Skrede A (1998). Comparative nutrient digestibility in dogs, blue fox, mink and rats.
American Society for Nutritional Sciences. Journal of Nutrition 128: 2676-2677

Anonymous (2012). "Rotamin" Feed Additive. Rota Mineral Corporation. http:// www. zeoliteproducer. com /rotamintr.html (Accessed: 11 January 2012)

AOAC (2000). Official Methods of Analysis. $17^{\text {th }}$ Edition, The Association of Official Analytical Chemists, Gaithersburg, MD, USA

Baran M S \& Kutay H C (1999). Zeolitin hayvan beslemede yem katkısı olarak kullanılması. Hayvancılık Dünyası Dergisi 3(25): 15-19

Baran M S, Demirel R, Yokuş B \& Kocabağlı N (2008). The effect of sorghum grain on live weight gain, feed conversion ratios and digestibility of nutrients in beef cattle. Journal of Animal Veterinary Advance 7: 11231127

Baran M S, Altaçli S, Kaplan O \& Deniz S (2017). The determination of nutrient value, digestibility and energy levels of mixed feeds used for ruminant nutrition by in vitro methods. Turkish Journal of Agriculture-Food Science and Technology 5(7): 832835

Crampton E W \& Maynard L A (1938). The relation of cellulose and lignin content to nutritive value of animal feeds. Journal of Nutrition 15: 383-395

Demirel R, Yokuş B, Şentürk D, Ketani M A \& Baran M S (2011). Effects of dietary zeolite on serum contents and feeding performance in rats. International Journal of Agriculture and Biology 3: 149-150

Dschaak C M, Eun J S, Young A J, Stott R D \& Peterson $S$ (2010). Effects of supplementation of natural zeolite on intake, digestion, ruminal fermentation, and lactational performance of dairy cows. Professional Animal Science 26: 647-654

Duncan D B (1995). Multiple Range and Multiple F-Tests. Biometrics, 11, pp. 1-42

Eleroğlu H \& Yalçın H (2012). Dietary effects of CaZeolite supplementation on water consumption and carcass caracteristics of broilers. Journal of Animal Veterinary Advance 11: 43-51

Eraslan G, Eşsiz D, Akdoğan M, Şahindokuyucu F \& Altıntaş L (2005). The effects of aflatoxin and sodium bentonit combined and alone on some blood electrolyte levels in broiler chickens. Turkish Journal of Veterinary and Animal Science 29: 601-605

Eser H, Yalçın S, Yalçın S \& Şehu A (2012). Effects of sepiolite usage in broiler diets on performance, 
Carcass traits and some blood parameters. Kafkas Universitesi Veteriner Fakültesi Dergisi 18(2): 313318

Fokas P, Zervas G, Fegeros K \& Zoiopoulos P (2004). Assessment of $\mathrm{Pb}$ retention coefficient and nutrient utilization in growing pigs fed diets with added clinoptilolite. Animal Feed Science and Technology 117: $121-129$

Husted W T, Mehen S, Hale W H, Little M \& Theurer B (1968). Digestibility of milo processed by different methods. Journal of Animal Science 27: 531-534

Johnson M A, Sweeney T F \& Muller L D (1988). Effects of feeding synthetic zeolite a and sodium bicarbonate on milk production nutrient digestion and rate of digesta passage in dairy cows. Journal of Dairy Science 71: 946-953

Larsen B Y T, Ostergard K, Hensen I, Knudsen K E \& Eggum B O (1991). Daily food intake and digestibiliy in rats. British Journal of Nutrition 65: 29-35

Martin-Kleiner I, Flegar-Meštrić Z, Zadro R, Breljak D, Janda S S, Stojković R, Marušić M, Radačić M \& Boranić M (2001). The effect of the zeolite clinoptilolite on serum chemistry and hematopoiesis in mice. Food Chemical Toxicology 39: 717-727
National Research Council (1995). Nutrient Requirements of Laboratory Animals, Fourth Revised Edition. National Academy Press, Washington, DC

Sarı M \& Çerçi I H (1993). Feeds, animal nutrition and nutrition diseases, Journal of Firat University Faculty of Veterinary Medicine, pp. 39-40

SPSS (1999). Statistical Package for the Social Sciences, Release 10.0. SPSS Inc. Illinois, Chicago, USA

Sweeney T F, Bull L S \& Hemken R W (1980). Effect of zeolite as a feed additive on growth performance in ruminants. Journal of Animal Science 51: 401-409

Şehu A, Çakır S, Eşsiz D \& Ergün L (2005). Preventive effects of HSCAS (Improved milbond-TX ${ }^{\circledR}$ ) on aflatoxicosis symptoms in quails. National Animal Nutrition Congress III, September 7-10, Adana, pp. 130-135

Tang Z G, Chen G Y, Li L F, Wen C, Wang T \& Zhou Y $M$ (2015). Effect of zinc-bearing zeolite clinoptilolite on growth performance, zinc accumulation, and gene expression of zinc transporters in broilers. Journal of Animal Science 93(2): 620-626

Van Soest P J (1987). Nutritional ecology of the ruminant. Second edition. Comstock Publishing Associates, Cornell University Press, Ithaca and London 